\title{
Dostoiévski e Graciliano Ramos: literaturas do subsolo*
}

Resumo: neste artigo, estabeleço uma comparação entre Fiódor Dostoiévski e Graciliano Ramos. 0 objetivo principal do texto é demonstrar de que modo as obras desses escritores se aproximam, a despeito das distâncias geográfica e temporal que os separam. Para tanto, partindo do momento histórico em que ambos produziram, analiso, sobretudo, as obras Memórias do subsolo e Angústia.

\begin{abstract}
I establish a comparison between Fyodor Dostoevsky and Graciliano Ramos. The aim of this text is to demonstrate how the literary productions of these writers are related, despite the geographical and temporal distances that separate them. For that, starting from the historical moment in which both produced, I analyze, above all, the works Notes from underground and Anguish.
\end{abstract}

Palavras-chave: Dostoiévski; Graciliano Ramos; Literatura russa; Literatura brasileira.

Keywords: Dostoevsky; Graciliano Ramos; Russian Literature; Brazilian Literature. 
"Política à parte, nunca notaram um parentesco muito vincado entre a alma brasileira e a alma russa? Pois eu desde já proclamo Dostoievsky o meu melhor professor de psicologia brasileira"

\section{Pinheiro de Lemos}

* Artigo submetido em 28 de abril de 2019 e aprovado em 21 de maio de 2019

0 presente artigo toma por base a dissertação de mestrado Dostoiévski e Graciliano Ramos: a literatura como salvação, orientada pelo Prof. Dr. André Dias e por mim defendida no âmbito do Programa de Pós-Graduação em Estudos de Literatura da Universidade Federal Fluminense.

** Doutorando em Estudos de Literatura (Literatura Comparada) e mestre em Estudos de Literatura (Literatura Brasileira e Teorias Literárias) pela Universidade Federal Fluminense. E-mail: paulomendonca@id.uff.br.

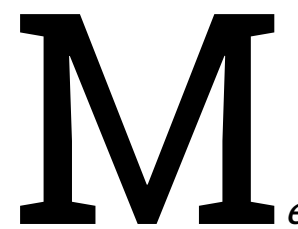

emórias do subsolo, obra publicada em 1864, é um dos primeiros escritos de Dostoiévski após a prisão, os quatro anos de trabalhos forçados e o exílio a que fora condenado por sua participação no círculo de Petrachévski, em que se debatiam ideias progressistas. Por seu turno, Angústia, de 1936, é entregue por Graciliano Ramos, sem revisão final, exatamente um dia antes de o escritor ser preso. Embora não o tenham acusado, oficialmente, de nenhum crime durante $o$ período de quase um ano em que permaneceu em prisões de Maceió e Rio de Janeiro, também pesava sobre Graciliano certa inclinação à esquerda, o que só viria a se configurar efetivamente oito anos após o escritor alagoano ser liberto, quando, a convite de Luís Carlos Prestes, aderiu oficialmente ao Partido Comunista Brasileiro.

À época em que Dostoiévski produziu Memórias do subsolo, a Rússia era um império comandado pelo tsar Alexandre II, que pouco antes implementara uma das reformas mais importantes da história do país, a abolição da servidão: "O Manifesto de Abolição da Servidão de 19 de fevereiro de 1861 foi um dos momentos mais marcantes da história russa...." O Brasil de 1936, à primeira vista, não se parece muito com a Rússia de meados do século XIX. Havíamos deixado a monarquia havia décadas e adotado o regime republicano, que, em tese, deveria representar uma mudança profunda na organização política do país. Sob o comando de Getúlio Vargas, o Brasil estava muito distante de se tornar um país democrático, antes o contrá-

${ }_{1}$ SEGRILLO, 2012, p. 149. 
rio. Prova maior disso é o fato de que em 1937, um ano após a publicação de Angústia, se instaura no país um regime que ficou conhecido na historiografia brasileira como Estado Novo (1937-1945), ou seja, mais um golpe de Estado, perpetrado por Vargas para tomar o poder: "O regime foi implantado no estilo autoritário, sem grandes mobilizações. O movimento popular e os comunistas tinham sido abatidos e não poderiam reagir; a classe dominante aceitava o golpe como coisa inevitável e até benéfica". ${ }^{2}$ Como atenta Boris Fausto, o golpe liderado por Getúlio Vargas foi preciso, pois eclodiu num momento político em que as forças opositoras nada podiam fazer para contê-lo.

Não obstante as obras de que tratamos tenham sido escritas sob regimes políticos aparentemente distintos, une-as o fato de que tais regimes, tanto o tsarismo russo quanto o "varguismo" brasileiro, tinham como predicado marcante o autoritarismo, em que o poder, via de regra, se concentra nas mãos de um grande líder. Parece-me que não é meramente figurativo mencionar essa "coincidência", haja vista que, para escritores como Dostoiévski e Graciliano Ramos, que sempre estiveram atentos à história de seus respectivos países, isto é, à sociedade em formação em que viviam, a opressão à liberdade de pensar e de exprimir-se intelectualmente sempre foi um grande problema com o qual tiveram de lidar em suas carreiras.

As sociedades de que tratamos, a russa do século XIX e a brasileira das primeiras décadas do século $\mathrm{XX}$, buscavam formar-se, desenvolver-se, tomando como modelo o padrão europeu. Aqui, há de se fazer um breve parêntese, pois pode parecer algo estranho mencionar a Europa como se a Rússia dela não fizesse parte, mas esse tratamento aponta para a questão identitária russa, que nunca pôde ser definitivamente resolvida. Confluência de diversas culturas e etnias, a Rússia afinal é europeia, asiática ou um país único que merece ser observado fora dos padrões geográficos convencionais? Esse é, sem dúvida alguma, um dos debates mais complexos dentro dos estudos histórico-geográficos a respeito da Rússia. Para compreendermos o imbróglio de maneira bastante sumária, há de

${ }^{2}$ FAUSTO, 2008, p. 200. 
se recordar das duas correntes que disputavam a hegemonia do pensamento crítico russo no século XIX. De um lado havia os ocidentalistas, defensores da definitiva europeização do país e que enxergavam nas grandes potências europeias (sobretudo na França) uma inspiração para a necessária modernização da Rússia; de outro, os eslavófilos, para os quais a Rússia era a "nação escolhida", destinada não a seguir preceitos estabelecidos, mas a apontar o caminho de um novo mundo que teria como sustentáculo a Igreja Ortodoxa. A questão da influência europeia na Rússia daquela época não passou ao largo dos comentários de Dostoiévski:

Somos realmente russos? Por que a Europa exerce sobre nós, sejamos quem formos, uma impressão tão forte e maravilhosa, e tamanha atração? (...) Toda a nossa vida se dispôs em moldes europeus, já desde a primeira infância. Será possível que algum de nós tenha podido resistir a esta influência, a este apelo, a esta pressão? Como foi que ainda não nos transformamos definitivamente em europeus? ${ }^{3}$

Nesse trecho de Notas de inverno sobre impressões de verão (obra escrita entre 1862 e 1863), Dostoiévski apresenta uma visão "assombrada" acerca da excessiva influência que a Europa exercia entre os russos. Todavia, embora fosse notadamente um partidário dos eslavófilos, seria injusto não destacarmos que "Dostoiévski é de uma perfeita imparcialidade artística", ${ }^{4}$ o que significa dizer que suas obras estão muito distantes de qualquer tipo de panfleto partidário de uma ideia. Finalmente, resta citar a concepção eurasiana, mais recente, segundo a qual o país deveria vivenciar como algo positivo sua singularidade geográfica e social. Em outras palavras, os russos deveriam aprender a conjugar a inevitável modernização europeia com as suas tradições históricas de maneira harmônica. Está claro que o debate é de enorme proporção e exige um aprofundamento a que só um estudo específico permitiria chegar.

Memórias do subsolo e Angústia exigem de nós uma atenção especial, uma vez que apresentam recordações de fatos que os próprios narradores vivenciaram. É fora de discussão

${ }^{3}$ DOSTOIÉVSKI, 2011, p. 79.

${ }^{4}$ CARPEAUX, 2015, p. 164. 
que os espaços vazios da memória, essencialmente lacunar, são preenchidos por nós de maneira nem sempre coerente. Diz-nos Luís da Silva: "A lembrança chega misturada com episódios agarrados aqui e ali, em romances. Dificilmente poderia distinguir a realidade à ficção". ${ }^{5}$ Nessa passagem, o próprio narrador de Angústia afirma que suas lembranças se misturam a episódios ficcionais. Então, como saber o que realmente é verdadeiro em seu discurso? Ora, simplesmente não saberemos. Temos acesso apenas ao discurso do narrador e nos restará, como leitores, a possibilidade da dúvida. Portanto, nunca alcançaremos a "verdade".

A lacuna, o vazio e a consequente (e por vezes proposital) falha na memória podem ser percebidos em muitas obras literárias, mas a peculiar contradição dos atos das personagens, evidenciada em seus discursos, certamente é uma característica que singulariza e aproxima os narradores de Memórias do subsolo e Angústia. Na obra de Dostoiévski, abundam exemplos da dualidade intrínseca à personagem. Sem dúvida, a primeira leitura da obra não é fácil para o leitor desavisado: "Menti a respeito de mim mesmo quando disse, ainda há pouco, que era um funcionário maldoso. Menti de raiva". ${ }^{6} \mathrm{O}$ que pensar de um sujeito que afirma, no início de sua narração, que o que acabamos de ler era mentira? Sobre a questão do livre arbítrio, tema bastante discutido no decorrer de toda a novela e muito caro aos romances posteriores de Dostoiévski, o "homem do subsolo" afirma, ainda na primeira parte da obra: "...o homem, seja ele quem for, sempre e em toda parte gostou de agir a seu bel-prazer e nunca segundo lhe ordenam a razão e o interesse". ${ }^{7} \mathrm{O}$ pensamento apresentado nesse trecho pelo narrador será refutado por ele mesmo no parágrafo final de suas memórias:

Bem, experimentai, por exemplo, dar-nos mais independência, desamarrai a qualquer de nós as mãos, alargai o nos-

\footnotetext{
${ }^{5}$ RAMOS, 2011, p. 41.

${ }^{6}$ DOSTOIÉVSKI, 2009, p. 16.

${ }^{7}$ Ibidem, p. 39.
} 
so círculo de atividade, enfraquecei a tutela e nós... eu vos asseguro, no mesmo instante pediremos que se estenda novamente sobre nós a tutela. ${ }^{8}$

Podemos perceber que não há unidade no que é exposto pela personagem ao longo de seu texto, o que, naturalmente, não deve ser considerado como um defeito da obra. Afinal, a incapacidade de apresentar uma coerência discursiva é uma das características mais marcantes desse narrador e corrobora seu caráter ambíguo.

À semelhança de Memórias do subsolo, também Angústia não nos apresenta uma narração das mais convidativas à primeira leitura. É necessário que o leitor "vença" a estranheza que lhe pode causar o discurso algo obscuro das primeiras páginas, em que não se explica ao leitor o que é e de que trata a narrativa que ele tem diante de si. É forçoso lembrar aqui de Walter Benjamin, ${ }^{9}$ para quem o verdadeiro narrador é aquele que não subestima a inteligência do outro, delegando a este a tarefa de desvendar sozinho o não dito. A prolixidade de Luís da Silva não aponta para um desnudamento completo. A construção de Graciliano Ramos parece seguir no sentido contrário, permitindo que, pouco a pouco, descubramos o caráter e a personalidade conflituosa de sua personagem. Nas primeiras páginas, encontramos apenas indícios do que está por vir: "O artigo que me pediram afasta-se do papel. É verdade que tenho cigarro e tenho álcool, mas quando bebo demais ou fumo demais, a minha tristeza cresce". ${ }^{10}$ Aqui, somos apresentados, indiretamente, aos hábitos do homem que nos conta sua vida, e desde o princípio criamos a imagem de um sujeito casmurro e solitário, o que se confirmará nas páginas seguintes.

Um aspecto que acentua a dramaticidade de Luís da Silva é a sua incapacidade de formar e possuir opinião própria. Assim como o narrador de Memórias do subsolo, que apresenta e defende teses contraditórias e bastante questionáveis, Luís da Silva não é capaz de formar opiniões concretas: "as minhas

\footnotetext{
${ }^{8}$ Ibidem, p. 146.

${ }^{9} \mathrm{Cf}$. BENJAMIN, 1987.

${ }^{10}$ RAMOS, Op. cit., p. 22.
} 
são fragmentadas, instáveis e numerosas". ${ }^{11}$ A contradição maior da personalidade de Luís da Silva parece residir no fato de ele concomitantemente rejeitar e ambicionar aquilo que tivera a ilusão de possuir por certo momento, isto é, Marina, que para o narrador de Angústia representa algo semelhante ao jantar com os "amigos" para o "homem do subsolo". Marina e o citado jantar são figuras que metaforizam a possibilidade de as personagens acessarem um nível mais alto a que jamais teriam acesso vivendo suas vidas mesquinhas. Em verdade, talvez seja mais correto dizer que metaforizam a impossibilidade de qualquer ascensão, já que tanto em Memórias do subsolo como em Angústia as personagens principais fracassam no intento de serem aceitas pelo outro.

No capítulo inicial de Memórias do subsolo, não se configuram ainda memórias propriamente ditas, senão uma defesa inconteste, porém desorganizada, de ideias e pensamentos filosóficos demasiado polêmicos. Em seu Problemas da poética de Dostoiévski, Bakhtin anota: "O herói dostoievskiano não é apenas um discurso sobre si mesmo e sobre seu ambiente imediato, mas também um discurso sobre o mundo: ele não é apenas um ser consciente, é um ideólogo. O homem do subsolo já é um ideólogo...". ${ }^{12}$ Das palavras de Bakhtin, destaco primeiramente o fato de o crítico russo considerar que $o$ "homem do subsolo" já é um ideólogo, haja vista que essa será talvez a primeira das grandes personagens dostoievskianas a defender ideias de caráter filosófico, ainda que o faça, repito, de maneira propositalmente confusa e contraditória. Na verdade, o "homem do subsolo" é o primeiro dos grandes "protagonistas ideólogos" das obras de Dostoiévski. Posteriormente seriam apresentados ao público Raskólnikov, Míchkin, Piotr Stiepánovitch e Ivan Karamázov, personagens centrais de Crime e Castigo, O idiota, Os demônios e Os irmãos Karamázov, respectivamente. Mas, afinal, qual a filosofia que sustenta o pensamento desse estranho narrador do subsolo? Para tentar responder a tal questionamento, parece-me válido recorrer

11 Ibidem, p. 59.

12 BAKHTIN, 2013, p. 87. 
àquela que talvez seja a maior das personagens já criadas por Dostoiévski, Ivan Karamázov, que desenvolve de maneira contundente a filosofia pioneiramente exposta pelo narrador de Memórias do subsolo.

A passagem que cito a seguir se encontra no capítulo "A revolta", em que Ivan apresenta a seu irmão Aliócha uma visão de mundo radical e revolucionária. Após relatar inúmeras atrocidades cometidas contra crianças (baseadas em notícias amplamente analisadas por Dostoiévski em seu Diário de um escritor), Ivan afirma a sua recusa completa pela harmonia eterna:

Não quero a harmonia, por amor à humanidade não a quero. Quero antes ficar com os sofrimentos não vingados. O melhor mesmo é que eu fique com meu sofrimento não vingado e minha indignação não saciada, ainda que eu não esteja com a razão. Ademais, estabeleceram um preço muito alto para a harmonia, não estamos absolutamente em condições de pagar tanto para entrar nela. É por isso que me apresso a devolver meu bilhete de entrada. E se sou um homem honrado, sou obrigado a devolvê-lo o quanto antes. E é o que estou fazendo. Não é Deus que não aceito, Aliócha, estou apenas lhe devolvendo o bilhete da forma mais respeitosa. ${ }^{13}$

A devolução do bilhete pode ser lida como uma metáfora que representa a não aceitação de um mundo irascível e impiedoso. Nesse sentido, é necessário questionar se vale a pena construir uma suposta harmonia à custa da lágrima de uma criança. Certamente, Ivan Karamázov nos diria que não, pois, para ele, as crianças são a personificação da pureza e inocência que não deveriam jamais ser maculadas. Interessante observar que, no princípio deste capítulo, Ivan diz a Aliócha que "queria falar do sofrimento humano em geral", ${ }^{14}$ mas que se deterá apenas no sofrimento das crianças, ainda que isso reduza consideravelmente a abrangência de sua argumentação. Ivan apresenta uma preocupação que sempre foi cara a Dostoiévski. Em Humilhados e ofendidos (1861), uma das personagens centrais é a pequena órfã Nelly, que terá retratada toda a sua

${ }^{13}$ DOSTOIÉVSKI, 2009, p. 340 - grifo do autor.

${ }^{14}$ DOSTOIÉVSKI, 2011, p. 327. 
miséria psicológica e social. Recordemos ainda que na cena final de Os irmãos Karamázov Aliócha dirige seu discurso a uma pequena plateia de crianças, capazes de compreender a complexidade das considerações feitas pelo ex-monge karamazoviano. Portanto, as crianças ocupam papel de destaque nas obras de Dostoiévski, não são seres inferiores, inábeis; pelo contrário, como assinala o Príncipe Míchkin em O idiota: "Não se deve esconder nada das crianças sob o pretexto de que são pequenas e ainda é cedo para tomarem conhecimento. Que ideia triste e infeliz!". ${ }^{15}$

Para Ivan Karamázov, em todo homem "esconde-se uma fera, a fera da cólera, a fera da excitabilidade lasciva com os gritos da vítima supliciada, a fera que desconhece freios, desacorrentada, a fera das doenças, da podagra e dos fígados adoecidos na devassidão". ${ }^{16}$ Essa visão descrente de Ivan em relação ao homem, ou seja, o entendimento de que a harmonia universal é algo verdadeiramente utópico, daí querer "devolver o bilhete de entrada", já está presente em Memórias do subsolo, obra na qual o narrador afirma que, "embora o homem já tenha aprendido por vezes a ver tudo com mais clareza do que na época bárbara, ainda está longe de ter-se acostumado a agir do modo que lhe é indicado pela razão e pelas ciências"; ${ }^{\prime 7}$ ainda: "Numa palavra, pode-se dizer tudo da história universal - tudo quanto possa ocorrer à imaginação mais exaltada. Só não se pode dizer o seguinte: que é sensata". ${ }^{18}$

A comparação entre o pensamento das personagens se justifica na medida em que ambas não acreditam em uma razão redentora que possa guiar a humanidade a um destino venturoso. Nesse ponto, Ivan Karamázov e "o homem do subsolo" se aproximam na dimensão do niilismo de que compartilham. No entanto, não me parece se tratar de um niilismo nietzschiano, que visa à substituição de valores absolutos historicamente constituídos. $\mathrm{Na}$ voz dessas personagens reverbera apenas a

${ }^{15}$ DOSTOIÉVSKI, 2012, p. 91

${ }^{16}$ DOSTOIÉVSKI, 2011, p. 334-335.

17 DOSTOIÉVSKI, 2009, p. 37 - grifo do autor.

18 Ibidem, p.43. 
definição dicionarizada e sintética da "filosofia da negação", isto é: "1. Descrença absoluta. 2. Doutrina segundo a qual nada existe de absoluto". ${ }^{19} \mathrm{~A}$ descrença das personagens as leva a agir de modo sincrônico, como se a existência futura pouco importasse (sem dúvida, essa é a impressão que nos resta ao fim das memórias, com o tom de desimportância que o narrador atribui ao escrito e, por extensão, à sua própria vida: "...não será melhor encerrar aqui as 'Memórias'? Parece-me que cometi um erro começando a escrevê-las") ${ }^{20}$. Estamos diante de personagens que, tentando erraticamente ser racionais, explicitam a impossibilidade de estabelecer relações sinceras em sociedade. A misantropia do "homem do subsolo" se explica, entre outros motivos, pelo fato de ele não ser capaz de perceber verdade nos finitos discursos humanos. Para esse sujeito, o homem sempre há de passar por cima de tudo e de todos a fim de viver intensamente sua presença sobre a terra. Quanto a Ivan Karamázov, seu ateísmo atesta cabalmente a incredulidade em quaisquer "infinitudes"; também ele se apresenta como um ser à margem e misantropo. Ivan não apenas recusa a harmonia, mas afirma que se apressará em dela se proteger.

Chama a atenção do leitor de Angústia, desde o princípio, o sentimento de repulsa que Luís da Silva nutre em relação a Julião Tavares. Já nas primeiras páginas, o arquirrival do narrador nos é apresentado sem que ainda saibamos exatamente 0 que ele representa na história que está sendo narrada. A "cara balofa" de Julião Tavares serve apenas para que comecemos a construir a imagem de um homem pouco agradável e motivador das perturbações enfrentadas por Luís da Silva.

Uma leitura desatenta de Angústia poderá supor que a trama gira em torno do crime cometido por seu narrador e personagem central da história. Nesse sentido, o objetivo de Luís da Silva ao escrever seu texto seria narrar as condições que o levaram a cometer o crime, o assassinato de Julião Tavares,

${ }^{19}$ FERREIRA, 2009, p. 578.

${ }^{20}$ DOSTOIÉVSKI, 2009, p. 145. 
fastígio do enredo e foco central em que vemos representada efetivamente toda a angústia da personagem que tem o poder da palavra em suas mãos. Em outra perspectiva, o crime de Luís da Silva pode ser visto quase como coadjuvante, um componente importante, sim, mas não o fato principal em torno do qual a narrativa se desenvolve. Caberia dizer, então, que o crime de Luís da Silva é nada mais que a consequência implacável de sua condição de ser/estar no mundo. Dito de outra forma: este angustiado narrador não poderia não matar, sob pena de ser incoerente com suas próprias convicções. Para Luís da Silva, portanto, assassinar o homem que lhe tomou a mulher que amava é um ato quase banal, o que ele próprio admite, indiretamente, quando expõe a incoerência da opinião dos homens:

Não há opinião pública: há pedaços de opinião, contraditórios. Uns deles estariam do meu lado se eu matasse Julião Tavares, outros estariam contra mim. No júri metade dos juízes de fato lançaria na urna a bola branca, metade lançaria a bola preta. Qualquer ato que eu praticasse agitaria esses retalhos de opinião. Inútil esperar unanimidade. Um crime, uma ação boa, dá tudo no mesmo. Afinal já nem sabemos o que é bom e o que é ruim, tão embotados vivemos. ${ }^{21}$

Em grande medida, o pensamento de Luís da Silva se aproxima daquele que talvez seja a mais conhecida personagem criada por Dostoiévski, o jovem estudante de Direito Raskólnikov, protagonista de Crime e castigo. Naquele que é o mais conhecido romance de Dostoiévski, até o nome do protagonista aponta para um traço marcante de sua personalidade, que também pode ser observado em Luís da Silva. No idioma russo, raskól (раскол) significa "cisão"; isto é, a personagem seria um sujeito cindido, dividido entre o bem e o mal, representante, na verdade, dos sentimentos ambíguos que constituem o ser humano de todos os tempos. As palavras de Luís da Silva acima expostas demonstram uma clara consciência de que a "razão humana" não precisa, e talvez nem possa, ser explicada de maneira lógica; é por isso que ele pode proferir sem culpa alguma: "Era evidente que Julião Tavares devia morrer. Não procurei investigar as razões desta necessidade. Ela se

${ }^{21}$ RAMOS, Op. cit., p. 163. 
impunha, entrava-me na cabeça como um prego". ${ }^{22}$ Ao afirmar que a morte de Julião Tavares era algo que deveria necessariamente acontecer, Luís da Silva reproduz a mesma convicção de Raskólnikov, quando este assassina a velha usurária com o aparente objetivo de roubá-la. Afinal, quem notaria a ausência daquela velha no mundo? O que ela representava senão 0 que há de mais abjeto na humanidade? Raskólnikov acredita, pois, que, ao assassinar sua senhoria, está fazendo um favor à sociedade, e que a morte de alguém como ela era algo perfeitamente justificável:

Cem, mil boas ações e iniciativas poderiam ser implementadas e reparadas com o dinheiro da velha, destinado a um mosteiro! Centenas, talvez milhares de existências encaminhadas; dezenas de famílias salvas da miséria, da desagregação, da morte, da depravação, das doenças venéreas - e tudo isso com o dinheiro dela. Mate-a e tome-lhe o dinheiro, para com sua ajuda dedicar-se depois a servir toda a humanidade e a uma causa comum: o que você acha, esse crime ínfimo não seria atenuado por milhares de boas ações ${ }^{23}$

Raskólnikov sabe que não empreenderá as boas ações de que fala (na passagem acima, o assassinato ainda não se concretizou). Todavia, valendo-se do poder de oratória e argumentação do estudante de Direito que é, elabora uma tese verossímil para convencer-se de que o crime não seria algo de todo negativo, tendo, inclusive, uma face bastante positiva se observado do ângulo adequado. Na verdade, ficamos sabendo que Raskólnikov comente o assassinato para se apoderar dos pertences da velha, o que acaba não se efetivando completamente, uma vez que ele esconde os pertences roubados embaixo de uma pedra e jamais volta para buscá-los. Dessa forma, o crime seria motivado por suas privações materiais, não por uma boa ação redentora de sua parte em relação à humanidade, que, obviamente, não poderia ser salva com os poucos pertences e o parco dinheiro da velha usurária. Prestes a se entregar às autoridades, já ao fim do romance, no momento em que confessa o crime a Sônia, Raskólnikov revela o verdadeiro motivo do assassinato:

\footnotetext{
22 Ibidem, p. 147 - grifo meu.

${ }^{23}$ DOSTOIÉVSKI, 2009, p. 80.
} 
Vê só: eu queria tornar-me um Napoleão e por isso matei... (...) Não foi para ajudar minha mãe que eu matei - isso é um absurdo! Eu não matei para obter recursos e poder, para me tornar um benfeitor da humanidade. Absurdo! Eu simplesmente matei; matei para mim, só para $\mathrm{mim}^{24}$

Não deixa de ser curioso notar que, na teoria elaborada por Raskólnikov, se até uma figura como Napoleão Bonaparte fora alçada a herói da História, por que ele deveria ser condenado por uma ação que, sob certa perspectiva, lhe parecia quase louvável e digna de elogios? Aqui, a aproximação com Luís da Silva é necessária e talvez constitua o ponto em comum mais interessante entre os assassinos em questão. Tanto para Luís da Silva quanto para Raskólnikov a morte de pessoas como Julião Tavares ou a velha usurária não afetaria negativamente a humanidade e, pelo contrário, poderia mesmo ser vista como um benefício para esta. No trecho em destaque, Raskólnikov afirma que matou para si, sem dar a Sônia maiores explicações. Em Angústia, Julião Tavares não é morto para servir de exemplo aos outros homens ou coisa que o valha; também aqui é o sentimento egoísta do assassino o que fala mais alto, afinal "Todos os dias nasce gente, morre gente. Isso não tem importância". ${ }^{25}$

Assim que cometem o crime, Raskólnikov e Luís da Silva entram em um estado de tormento e quase loucura. Ambos estavam convencidos, em um primeiro momento, de que suas ações poderiam representar um bem para a humanidade, o que obviamente não se concretiza. No início da segunda parte de Crime e castigo, logo após o assassinato, Raskólnikov parece já estar mergulhado em certa confusão mental: "No primeiro instante pensou que fosse enlouquecer (...) 'O que é isso, será que já está começando, será que o suplício já está chegando?' (...) 'Ora, que coisa está acontecendo comigo!'”. ${ }^{26}$ Nesses trechos, 0 protagonista do romance de Dostoiévski começa a vivenciar seu castigo, que é a própria consciência do erro cometido. Posteriormente, convencido por Sônia, Raskólnikov se entregará

\footnotetext{
${ }^{24}$ Ibidem, p. 423-427.

${ }^{25}$ RAMOS, Op. cit., p. 214.

${ }^{26}$ DOSTOIÉVSKI, 2009, p. 103-104.
} 
à polícia. Entretanto, como podemos perceber, a condenação a trabalhos forçados na Sibéria não é sua verdadeira pena.

O que foi observado em relação à condenação de Raskólnikov em Crime e castigo serve de maneira quase análoga para a nossa leitura de Angústia. Embora o romance termine antes de sabermos se Luís da Silva será efetivamente preso, ou se sobre ele recai, de fato, alguma suspeita formal, a consciência também é o desencadeador dos devaneios e assombros que afetam a personagem. Após enforcar Julião Tavares, que não apenas roubara sua mulher como personificava os sentimentos mais abjetos que Luís da Silva podia enxergar em um homem, o narrador de Angústia elabora um labiríntico discurso que acentua ainda mais seu martírio. As passagens finais do romance, para Graciliano Ramos, constituem um momento de confusão e repetição dentro do texto, que precisava ser revisto e reescrito. Acredito, porém, que o monólogo final da obra é algo positivo para a narrativa e destaca exatamente o desajuste mental de Luís da Silva:

O pensamento partia-se. Ia cair na cama, delirar, morrer. A carne estremecia, os pés dos cabelos doíam-me. De quando em quando levava a mão ao rosto, e o contato da palma com a barba crescida arrancavam-me palavrões obscenos grunhidos em voz baixa. Um porco, parecia um porco. Esta comparação não me entristecia. Desejava ser como os bichos e afastar-me dos outros homens. (...) Fatos possíveis misturavam-se a coisas absurdas. ${ }^{27}$

Nessa passagem, a comparação com um animal sujo demonstra o olhar aparentemente negativo que Luís da Silva lança sobre si mesmo após o assassinato de Julião Tavares. É curioso notar que tal relação não parece incomodá-lo, haja vista que, como o próprio diz, um animal poderia ao menos viver isolado dos outros homens. Os efeitos físicos da loucura que afetam a personagem se fundem à confusão psíquica e já não é possível distinguir com exatidão a realidade dos acontecimentos inverossímeis. Em suma, Luís da Silva experimenta um castigo anterior a qualquer julgamento formal. À semelhança do que ocorre em Crime e castigo, o narrador-personagem de Angústia tem como principal juiz a própria

${ }^{27}$ RAMOS, Op. cit., p. 216. 
consciência, que o condena a uma pena da qual será impossível livrar-se. Às duas personagens, as palavras do "homem do subsolo" caem como uma luva: "...não só uma dose muito grande de consciência, mas qualquer consciência, é uma doença. Insisto nisso". ${ }^{28}$

O crime de Luís da Silva é um fracasso, porque o sentimento de superioridade experimentado pela personagem dura apenas o tempo em que ele executa a ação. Ainda assim, é preciso destacar que ter praticado aquilo que conjecturara fazer demonstra a coragem do sujeito cansado diante da impossibilidade de realizar seus objetivos. $O$ assassinato cometido por Luís da Silva, aliás, é o único momento em que o indivíduo enfrenta diretamente as normas sociais. Em Memórias do subsolo, além do esbarrão que o narrador resolve devolver no oficial que o humilhara, há pelo menos outros dois momentos em que a personagem procura agir de maneira "não convencional" com o objetivo de se fazer notar. Vejamos.

Recordemos que o "homem do subsolo" não fora convidado por seus "colegas" para o jantar, do qual tomara conhecimento absolutamente por acaso ao visitar Antón Antônitch: "Pois bem, de uma feita, numa quinta-feira, não suportando mais a minha solidão e sabendo que, nesse dia, estava fechada a porta de Antón Antônitch, lembrei-me de Símonov" ${ }^{29} \mathrm{~A}$ partir do que é dito pela personagem, podemos inferir que ela sai em busca de qualquer companhia que possa dirimir de alguma maneira a sua insuportável solidão. Ao entrar na casa de Símonov, o "homem do subsolo" se depara com um grupo reunido: "Nenhum deles notou a minha chegada, o que era estranho até, pois fazia anos que não nos víamos. Provavelmente, consideravam-me algo semelhante à mais ordinária das moscas" ${ }^{30}$ Agora, a afronta maior do "homem do subsolo" será se convidar para o jantar em que comemorariam a partida de Zvierkóv, oficial de quem nunca fora amigo. Daqui em diante, acompanhamos de perto as humilhantes situações pelas quais passa

\footnotetext{
${ }^{28}$ DOSTOIÉVSKI, 2009, p. 19.

29 Ibidem, p. 74.

${ }^{30}$ DOSTOIÉVSKI, 2009, p. 75.
} 
a personagem a fim de ir ao encontro: "...havia até um pretexto ponderável para não ir: estava sem dinheiro". ${ }^{31}$ Ainda que não dispusesse de recursos para comparecer adequadamente ao jantar, o "homem do subsolo" faz questão de permanecer: "Ficaríeis satisfeitos se eu fosse embora, senhores. Por nada deste mundo! Ficarei aqui sentado, de propósito, e beberei até o fim, em sinal de que não lhes atribuo a menor importância". ${ }^{32}$ Nesse trecho, o objetivo principal do narrador, à primeira vista, parece ser apenas vingar-se dos antigos companheiros de escola, retribuir-lhes a mesma sensação de menosprezo que ele experimentava todos os dias. Contudo, o caráter paradoxal da personagem se fará notar logo em seguida: "'Oh, se ao menos soubessem de que sentimentos e ideias sou capaz e como sou culto!' (...) Mas os meus inimigos comportavam-se como se eu nem estivesse na sala". ${ }^{33}$ Uma vez mais, é o desejo de aceitação que fala mais alto, apesar de todas as desonras sofridas. Esse sentimento também pode ser encontrado no romance de Graciliano Ramos.

Como ficou dito parágrafos atrás, para Luís da Silva, Marina representa algo semelhante ao jantar com os "amigos" para o "homem do subsolo". Em ambas as situações, trata-se da busca de inserção e convívio em um grupo social específico. Todavia, a afronta do narrador de Dostoiévski é algo ativo, o personagem participa de um jantar para o qual não fora convidado e insiste em permanecer mesmo não sendo querido pelos "amigos". No romance de Graciliano, em contrapartida, encontramos certa passividade por parte de Luís da Silva em relação a Marina. Tê-la como mulher o faria membro da sociedade de alguma forma, pois, ainda que ela fosse uma moça pobre, sua beleza poderia servir como prova de que Luís da Silva, apesar de tudo, era um homem; afinal: "um homem é um homem", ${ }^{34}$ escreve ele para convencer-se de que também faz parte do grupo de animais racionais.

\footnotetext{
31 Ibidem, p. 80.

32 Ibidem, p. 93.

33 Ibidem, p. 95.

${ }^{34}$ RAMOS, Op. cit., p. 55.
} 
Além de ser a representação metafórica, para Luís da Silva, de uma possibilidade de inserção na sociedade, Marina ainda merece ser lembrada nesta leitura na medida em que podemos compará-la à prostituta Liza de Memórias do subsolo. É o próprio Luís da Silva que qualifica Marina, quando esta o troca por Julião Tavares: "Escolher marido por dinheiro. Que miséria! Não há pior espécie de prostituição". ${ }^{35}$ Porém, a semelhança entre as duas personagens parece terminar por aqui. Enquanto Liza representa a personagem humilhada devido às condições impostas pela vida, Marina é a moça ingênua, ignorante mesmo, que sequer faz ideia de que também é uma "humilhada e ofendida" dostoievskiana. Se os narradores das obras se aproximam devido à terrível consciência que têm do que representam para o mundo, Liza e Marina se diferem exatamente pelo fato de que somente a primeira possui tal consciência. Nesse sentido, Marina é punida apenas com o castigo mundano, ficar grávida e malvista pela sociedade, mas não pelo maior de todos que já conhecemos: a consciência de sua insignificância no mundo. Finalmente, importa dizer que a consciência de Liza, seu "castigo", só lhe parece claro após o longo discurso do "homem do subsolo", em que este, dirigindo-se à moça frágil que vê diante de si, não resiste à tentação de falar de si mesmo: "Se eu tivesse família, desde criança, não seria como sou agora. Penso nisso com frequência". ${ }^{36}$ Compartilhar sua desgraça é a forma encontrada pelo narrador para conscientizar Liza de sua condição de ser/estar no mundo. Quando a prostituta descobre que outros sofrem como ela, o "homem do subsolo", no caso, passa a enxergar uma saída possível para as aflições que enfrenta na vida. A passagem de $\mathrm{Me}$ mórias do subsolo acima merece ainda ser comparada com as palavras de Luís da Silva: "Sempre brinquei só. Por isso cresci assim besta e mofino". ${ }^{37}$ Como vemos, também o narrador de Angústia atribui o seu modo de ser à solidão e falta de companhia, nas quais podemos perfeitamente ler a inexistência da

\footnotetext{
35 Ibidem, p. 97.

${ }^{36}$ DOSTOIÉVSKI, 2009, p. 109.

${ }^{37}$ RAMOS, Op. cit., p. 125.
} 
presença familiar em sua criação e formação. O "homem do subsolo" e Luís da Silva classificam-se com adjetivos bastante negativos (insensível, besta, mofino), o que explicita e acentua a visão derrotista que ambos desenham de si mesmos.

As ações dos narradores de Angústia e Memórias do subsolo objetivam, em primeiro lugar, fazer com que as personagens se integrem à sociedade, mas vimos aqui que, além disso, elas também podem significar o simples desejo de vingança. Seja qual for a real finalidade dos atos praticados, considerando que haja uma finalidade específica, acredito que nas duas obras seus protagonistas não logram êxito em seus intentos. O "homem do subsolo" termina seu texto afirmando que talvez tenha sido um erro iniciá-lo; Luís da Silva conclui com um monólogo esquisito e sombrio, para dizer o mínimo. Mas, algum de nós poderia esperar algo diverso? $\mathrm{O}$ fracasso das personagens é o fracasso do "homem que é um homem"; quer dizer, do homem que tem consciência de sê-lo existencialmente, não apenas fisicamente. Memórias do subsolo e Angústia são obras existencialistas por excelência (a primeira avant la lettre, já que pode ser considerada uma das narrativas fundadoras de tal corrente filosófica), em que as personagens se veem "nuas" e solitárias ao perceberem sua condição de seres humanos livres. Pôr em prática a liberdade a que estão condenadas não as leva ao paraíso, mas a um novo começo, no qual a vida dos sujeitos continuará fora de nossa presença leitora. $\mathrm{E}$ continuará miserável como era antes, porque os atos que observamos, embora envernizados de certa coragem aparente, não foram e não serão capazes de inserir o homem no meio social nem de vingá-lo deste.

\section{Referências bibliográficas}

BAKHTIN, Mikhail. Problemas da poética de Dostoiévski. $5^{a}$ ed. Tradução Paulo Bezerra. Rio de Janeiro: Forense Universitária, 2013.

BENJAMIN, Walter. Obras escolhidas. Magia e técnica, arte e 
política. $3^{\mathrm{a}}$ ed. Tradução Sérgio Paulo Rouanet. São Paulo: Editora Brasiliense, 1987.

CARPEAUX, Otto Maria. A cinza do purgatório. $3^{\mathrm{a}}$ ed. Balneário Camboriú: Livraria Danúbio Editora, 2015.

DOSTOIÉVSKI, Fiódor. Memórias do subsolo. $6^{\mathrm{a}}$ ed. Tradução Boris Schnaiderman. São Paulo: Editora 34, 2009.

Crime e castigo. $2^{\mathrm{a}}$ ed. Tradução Paulo Bezerra. São Paulo: Editora 34, 2009.

Os irmãos Karamázov. $2^{\mathrm{a}}$ ed. Tradução Paulo Bezerra. São Paulo: Editora 34, 2009.

O crocodilo e Notas de inverno sobre impressões de verão. $4^{\mathrm{a}}$ ed. Tradução Boris Schnaiderman. São Paulo: Editora 34, 2011.

O idiota. $3^{\mathrm{a}}$ ed. Tradução Paulo Bezerra. São Paulo: Editora 34, 2012.

FAUSTO, Boris. História concisa do Brasil. $2^{a}$ ed. São Paulo: Edusp, 2008.

FERREIRA, Aurélio Buarque de Holanda. Miniaurélio: o dicionário da língua portuguesa. $7^{\text {a }}$ ed. Curitiba: Editora Positivo, 2009.

LEMOS, Pinheiro de. "Das Estepes às Caatingas". In: GOMIDE, Bruno Barretto. Da estepe à caatinga: o romance russo no Brasil (1887-1936). São Paulo: Edusp, 2011. Pp. 745-747.

RAMOS, Graciliano. Angústia. Edição Comemorativa dos 75 anos. Rio de Janeiro: Record, 2011.

SEGRILLO, Angelo. Os russos. São Paulo: Editora Contexto, 2012. 